\title{
EDITORIAL
}

\section{Who's (still) afraid of talc?}

\author{
M. Noppen
}

\section{TALC IS DIRT ${ }^{\#}$}

Any pulmonologist who has ever visited a pleural disease or pneumothorax session at a major international conference or symposium, has heard the famous exclamation of my good friend Prof. Richard Light, one of the "popes" of pleural disease. Prof. Light is an exponent of the (mainly North American) school of pulmonologists who do not like talc as a pleurodesis agent. These pulmonologists do not like it to be used in malignant effusion, and they certainly do not like it to be used in young people with benign diseases, such as spontaneous pneumothorax!

The main reason for this is fear. Fear that talc is not safe. Fear that talc induces acute respiratory distress syndrome (ARDS). Fear that talc induces death. Fear that talc excludes eventual pulmonary surgery or transplantation. Fear that talc induces impaired lung function. Fear that talc causes mesothelioma or cancer. Fear that talc makes surgeons angry (now that is one I can understand!). Fear, however, is a bad advisor; knowledge is a much better one. Let us see what is known about talc safety.

\section{THE SHORT-TERM SAFETY OF TALC}

Although some authors have observed respiratory failure, ARDS and even death after talc pleurodesis [1, 2], others have not, even in large series [3-5]. In any case, these serious complications are extremely rare (41 out of 4,030 patients in a study by SAHN [6]) and have only been observed in studies from the USA, Brazil and New Zealand, and not, for instance, in Europe or Israel. The occurrence of these serious complications seemed to be independent of the underlying disorder (malignant effusion or pneumothorax), the volume of talc used (2-10 g) or the method of administration (slurry or poudrage). An important observation, however, was that talc dissemination has been observed in virtually all organs when North American or Brazilian talc was used $[7,8]$ but not when extremely high doses were used [9], whereas no talc dissemination occurred when European, size-calibrated talc was used [10]. Lung damage occurs only when small particlesized talc is used, and not after exposure to large particle-sized talc [11]. Small particle-sized talc causes more inflammation and impaired gas exchange than large particle-sized talc [12].

\section{STATEMENT OF INTEREST: None declared.}

CORRESPONDENCE: M. Noppen, Respiratory Dept, AZ VUB, 101 Laarbeeklaan, Brussels, Belgium. Fax: 32 24775515. E-mail: marc.noppen@az.vub.ac.be

\#: exclaimed at $100 \mathrm{~dB}$ !
Therefore, the observed differences in serious complications within various countries can mainly be attributed to differences in talc used, that is, differences in the number or proportion of small-sized talc particles [13]. This hypothesis is corroborated by the fact that particle size is only mentioned in one as yet unpublished paper describing serious complications (talc particle diameter of $5-70 \mu \mathrm{m}$ ), in which it was observed that complications occur more often when small particle-sized talc is used (cut-off $5 \mu \mathrm{m}$ ), and, finally, by the results of a large, prospective, observational European study in which no case of ARDS was observed in a cohort of 558 patients treated with talc poudrage [14]. The conclusion is that talc is safe if size-calibrated talc is used and at normal dosages.

\section{THE LONG-TERM SAFETY OF TALC}

Medical thoracoscopic talc poudrage is not only simple and feasible under local anaesthetic [15-17] but it is also safe in the long term. A thorough review published in 1979 [18] was unable to show any serious or well-documented side-effects of talc poudrage, even after a long-term observation. In a large series of patients observed for $>20 \mathrm{yrs}$, LANGE et al. [19] documented that talc did not provoke pulmonary fibrosis. However, a mild but asymptomatic restrictive impairment in pulmonary function was observed. This has also been observed by other authors in the months following the procedure, although pulmonary function improved within 1 yr [16]. VISKUM et al. [20] re-examined 99 patients 22-35 yrs after talc poudrage for spontaneous pneumothorax and found no serious complications or side-effects, as well as a recurrence rate of only $2.5 \%$. In summary, talc does not cause cancer or mesothelioma, it does not cause pulmonary fibrosis and it does not cause significant impairment in pulmonary function in the long term. Does it cause angry surgeons? In my experience, the answer is yes. Therefore, I would like to refer them to the recent surgical literature. For instance, CARDILLO et al. [21] have performed video-assisted thoracic surgery (VATS) talc poudrage in 861 spontaneous pneumothorax patients. They found no significant short- or long-term complications, and even checked pulmonary function in a subgroup of 29 patients, which all remained normal. Other brave surgeons include PletincKx et al. [22] and LuH et al. [23]. Finally, does talc poudrage make later thoracic or thoracoscopic surgery impossible? No! DODDOLi et al. [24] showed that VATS re-intervention after previous talc poudrage up to 13 yrs previously was feasible in the majority of patients. In only 12 out of 39 patients was a re-conversion to (successful) thoracotomy necessary. 
Therefore, yes, this procedure is more difficult but not impossible.

Your honours, Mr Editors-in-Chief, I rest my case! I have shown, based on abundant peer-reviewed evidence, that talc poudrage is safe for pleurodesis, in malignant effusion and in spontaneous pneumothorax. Furthermore, talc is the most effective chemical pleurodesis agent, in both malignant effusion and in pneumothorax [16, 25-29]. Its mechanism of action is, as yet, incompletely understood. This is demonstrated by NAJMUNNISA et al. [30] in the current issue of the European Respiratory Journal (ERJ), in that talc mediates a dramatic decrease of angiogenic activity within the pleural space in patients with malignant effusions, which supports the use of talc as a sclerosant agent in these patients.

Furthermore, simple thoracoscopic talc poudrage is as efficient as more elaborated surgical VATS procedures. Size-calibrated talc does not cause ARDS or death. In the long term, talc does not cause cancer, pulmonary fibrosis, impaired thoracic surgical re-interventions or decreased pulmonary function, as shown by GYÖRIK et al. [31] in the current issue of the ERJ. This makes talc suitable for pleurodesis in benign conditions, such as spontaneous pneumothorax. Finally, it is by far the cheapest pleurodesis agent! I think this must be convincing evidence for every jury.

Finally, I would like to pay my respects to my friend Prof. Light, and I look forward to speaking to him about pleurodesis at various conferences around the world. I refer here to a French dictum that says: de la confrontation des idées jaillisse la lumière (truth emerges from the confrontation of opinions). This is how science works.

\section{REFERENCES}

1 Rehse DH, Aye RW, Florence MG. Respiratory failure following talc pleurodesis. Am J Surg 1999; 177: 437-440.

2 Brant A, Eaton T. Serious complications with talc slurry pleurodesis. Respirology 2001; 6: 181-185.

3 Weissberg D, Ben-Zeev I. Talc pleurodesis. Experience with 360 patients. J Thorac Cardiovasc Surg 1993; 106: 689-695.

4 Cardillo G, Facciolo F, Carbone L, et al. Long-term followup of video-assisted talc pleurodesis in malignant recurrent pleural effusions. Eur J Cardiothorac Surg 2002; 21: 302-306.

5 Viallat JR, Rey F, Astoul P, Boutin C. Thoracoscopic talc poudrage pleurodesis for malignant effusions. A review of 360 cases. Chest 1996; 110: 1387-1393.

6 Sahn SA. Is talc indicated for pleurodesis? Pro: talc should be used for pleurodesis. J Bronchol 2002; 61: 35-38.

7 Kennedy L, Harley RA, Sahn SA, Strange C. Talc slurry pleurodesis. Pleural fluid and histological analysis. Chest 1995; 107: 1707-1712.

8 Werebe EC, Pazetti R, Milanez de Campos JR. Systemic distribution of talc after intrapleural administration in rats. Chest 1999; 115: 190-193.

9 Montes JF, Ferrer J, Villarino MA, Baeza B, Crespo M, Garcia-Valero J. Influence of talc dose on extrapleural talc dissemination after talc pleurodesis. Am J Respir Crit Care Med 2003; 168: 1648-1654.

10 Fraticelli A, Robaglia-Schlupp A, Riera A, MonjanelMouterde S, Cau P, Astoul P. Distribution of calibrated talc after intrapleural administration: an experimental study in rats. Chest 2002; 122: 1737-1741.

11 Ferrer J, Montes JF, Villarino MA, Light RW, GarciaValero J. Influence of particle size on extrapleural talc dissemination after talc slurry pleurodesis. Chest 2002; 122: 1018-1027.

12 Maskell NA, Lee YG, Gleeson FV, Hedley EL, Pengelly G, Davies RJ. Randomized trials describing lung inflammation after pleurodesis with talc of varying particle size. Am J Respir Crit Care Med 2004; 170: 377-382.

13 Ferrer J, Villarino MA, Tura JM, Traveria A, Light RW. Talc preparations used for pleurodesis vary markedly from one preparation to another. Chest 2001; 119: 1901-1905.

14 Janssen JP, Collier G, Tassi G, et al. The European multicentre study on the safety of talc poudrage in malignant pleural effusion (the SOTIM study). Lancet 2007; (In press).

15 Boutin C, Viallat JR, Aelony J. Practical Thoracoscopy. Berlin, Springer, 1991.

16 Tschopp JM, Brutsche M, Frey JG. Treatment of complicated spontaneous pneumothorax by simple talc pleurodesis under thoracoscopy and local anesthesia. Thorax 1997; 52: 329-332.

17 Gillet-Juvin K, Guérin JC. Le talcage sous thoracoscopie des pneumothorax par rupture de bulles d'emphysème. Etude de 71 cas. [Talc therapy during thoracoscopy of pneumothorax due to rupture of the bullae in emphysema. A study of 71 cases.]. Rev Mal Respir 1991; 8: 289-293.

18 A survey of the long-term effects of talc and kaolin pleurodesis. Research Committee of the British Thoracic Association and the Medical Research Council Pneumoconiosis. Br J Dis Chest 1979; 73: 285-288.

19 Lange P, Mortensen J, Groth S. Lung function 22-35 years after treatment of idiopathic spontaneous pneumothorax with talc poudrage or simple drainage. Thorax 1988; 43: 559-561.

20 Viskum K, Lange P, Mortensen J. Long-term sequelae after talc pleurodesis for spontaneous pneumothorax. Pneumologie 1989; 43: 105-106.

21 Cardillo G, Carleo F, Giunti R, et al. Videothoracoscopic talc poudrage in primary spontaneous pneumothorax: a single-institution experience in 861 cases. J Thorac Cardiovasc Surg 2006; 131: 322-328.

22 Pletinckx P, Muysoms F, De Decker C, Daeter E, Claeys D. Thoracoscopic talc pleurodesis for the treatment of spontaneous pneumothorax. Acta Chir Belg 2005; 105: 504-507.

23 Luh SP, Tsai TP, Chou MC, Yang PC, Lee CJ. Videoassisted thoracic surgery for spontaneous pneumothorax: outcome of 189 cases. Int Surg 2004; 89: 185-189.

24 Doddoli C, Barlesi F, Fraticelli A, et al. Video-assisted thoracoscopic management of recurrent primary spontaneous pneumothorax after prior talc pleurodesis: a feasible, safe and efficient treatment option. Eur J Cardiothorac Surg 2004; 26: 889-892. 
25 Kolschmann S, Ballin A, Gilissen A. Clinical efficacy and safety of thoracoscopic talc pleurodesis in malignant pleural effusion. Chest 2005; 128: 1431-1435.

26 Kilic D, Akay H, Kavukcu S, et al. Management of recurrent malignant pleural effusion with chemical pleurodesis. Surg Today 2005; 35: 634-638.

27 Aelony Y, Yao JF. Prolonged survival after talc poudrage for malignant pleural mesothelioma: case series. Respirology 2005; 10: 649-655.

28 Shaw P, Agarwal R. Pleurodesis for malignant pleural effusions. Cochrane Database Syst Rev 2004; 1: CD002916.
29 Milanez JR, Vargas FS, Filomeno LT, Fernandez A Jatene A, Light RW. Intrapleural talc for the prevention of recurrent pneumothorax. Chest 1994; 106: 1162-1165.

30 Najmunnisa N, Mohammed KA, Brown S, et al. Talc mediates angiostasis in malignant pleural effusions via edostatin induction. Eur Respir J 2007; 29: 761-769.

31 Györik S, Erni S, Studler U, Hodek-Wuerz R, Tamm M, Chhajed PN. Long-term follow-up of thoracoscopic talc pleurodesis for primary spontaneous pneumothorax. Eur Respir J 2007; 29: 757-760. 